\title{
Pelatihan Desain Kemasan bagi Pemula pada Pelaku Usaha Mikro dan Kecil Kota Banjarbaru, Kalimantan Selatan
}

\section{Tri Wahyu Qur'ana*1, Abdurahman Sidik², Hayati Noor ${ }^{3}$, Adani Dharmawati4}

\author{
1,2,3,4Program Studi Teknik Informatika, Fakultas Teknologi Informasi, Universitas Islam Kalimantan \\ Muhammad Arsyad Al Banjari, Indonesia \\ e-mail: twqurana@gmail.com ${ }^{1}$, abdurrahmansidik30@gmail.com ${ }^{2}$, adhienk.athie@gmail.com $^{3}$,
} adani.dharmawati@gmail.com ${ }^{4}$

\begin{abstract}
Abstrak
Latar dan dasar desain kemasan yang dimiliki oleh pelaku usaha mikro dan kecil Kota Banjarbaru belum mampu mengangkat nilai jual produk dan juga pemasaran yang belum mampu berkompetisi dengan produk dari luar daerah yang tentunya berpengaruh besar terhadap laba penjualan produk dari usaha mikro dan kecil tersebut. Kegiatan Pengabdian kepada masyarakat ini bertujuan membantu para pelaku usaha mikro dan kecil menambah wawasan, pemberdayaan teknologi tepat guna, dan juga penggunaan media digital dalam membuat desain kemasan pada label kemasan, serta pendampingan untuk menghasilkan kualitas serta inovasi baru pada label kemasan. Metode pelaksanaan kegiatan yaitu metode ceramah dengan teknik presentasi dilanjutkan dengan diskusi dan pelatihan membuat desain kemasan dengan memanfaatkan aplikasi android yang ada pada ponsel seluler masing-masing peserta serta pelatihan food fotografi. Evaluasi kegiatan ini dilakukan dengan dua cara yaitu memberikan proyek latihan desain kemasan sesuai produk masing-masing peserta dan kuesioner yang dilaksanakan sebelum dan sesudah kegiatan pelatihan desain kemasan. Hasil dari pelatihan yang telah dilaksanakan menunjukan bahwa adanya respon yang baik dari peserta pelatihan, serta peningkatan nilai posttest sebesar 88.87\% dari nilai pretest sebesar 44,75\%. Hal ini menunjukan bahwa ada pengaruh yang signifikan setelah dilakukan pelatihan desain kemasan.
\end{abstract}

Kata kunci: Desain, Kemasan, Usaha

\begin{abstract}
The background and basis of packaging design owned by the Micro and Small Business Actors of Banjarbaru City have not been able to increase the selling value of the product and also the marketing and have not been able to compete with products from outside the region which certainly has a major effect on the profit of product sales from the micro and small businesses. This community service activity aims to help micro and small business actors gain insight, empower appropriate technology, and also use digital media in making packaging designs on packaging labels, as well as assistance to produce quality and new innovations in packaging label design. The method of implementing the activity is the lecture method with presentation techniques followed by discussions and training on making packaging designs using the android application on each participant's cellphone as well as food photography training. The evaluation of this activity is carried out in two ways, namely providing a packaging design training project according to the products of each participant and a questionnaire which is carried out before and after the packaging design training activity. The results of the training that have been carried out show that there is a good response from the training participants, as well as an increase in the posttest score by 88,87\% from the pretest score of 44,75\%. This shows that there is a significant effect after packaging design training is carried out.
\end{abstract}

Keywords: Beginners, Packaging Label, Training

\section{PENDAHULUAN}

Jumlah UMKM di Indonesia yang terus bertambah bagai dua sisi mata uang. Di satu sisi, geliat masyarakat Indonesia yang tinggi dalam membuat bisnis sendiri sangat baik dalam membantu mendorong perekonomian nasional. Di sisi lain, banyak juga yang mendirikan usaha hanya karena ikut-ikutan tren. Alasan terakhir inilah yang membuat banyak pelaku UMKM jalan di tempat dalam mengembangkan usahanya karena minimnya inovasi. Akhirnya banyak usaha yang hanya bertahan selama 1-2 tahun, kemudian tutup usaha karena produk atau jasa yang ditawarkan tidak kuat atau kalah bersaing. Banyak pelaku UMKM di Indonesia yang hanya 
menjalankan bisnis berdasarkan ikut-ikutan tanpa melihat potensi diri yang dimilikinya. Selain itu banyak pelaku UMKM yang masih gagap teknologi yang tidak tahu tentang kemajuan teknologi serta tidak bisa mengoperasikannya, seperti marketplace online, media sosial, dan pembayaran digital.

Kekuatan iklan televisi sebagai media komunikasi telah menurun drastis dengan semakin banyaknya media alternatif dan semakin mudahnya konsumen berpindah-pindah saluran ketika TV menayangkan iklan komersil semakin memperburuk keadaan. Para tenaga pemasaran produk pun akhirnya mencari cara-cara baru untuk menyampaikan pesan kepada konsumen dengan hasil yang sesuai dengan biaya yang mereka keluarkan, menyadari bahwa kemasan bisa menjadi kunci utama untuk mengkomunikasikan merek produk mereka kepada konsumen.

Menurut Klimchuk dan Krasovec (2007) sejarah desain kemasan berkaitan erat dengan setiap aspek perubahan budaya manusia. Perkembangan teknologi, material, produksi, dan kondisi masyarakat sebagai konsumen yang terus berubah mengakibatkan perlunya sebuah kemasan yang tujuan dasarnya bukan hanya sekedar melindungi, namun juga sebagai tempat menyimpan produk agar tahan lama, mempermudah proses distribusi dan mengirimkan barang, mengidentifikasi dan membedakan produk kita dengan produk kompetitor lainnya di pasar, serta menjadi sarana untuk mengkomunikasikan isi produk secara visual.

UMKM adalah singkatan dari usaha mikro, kecil, dan menengah. Pemerintah menetapkan definisi UMKM dan kriterianya dalam Undang-Undang Nomor 20 Tahun 2008 tentang Usaha Mikro, Kecil, dan Menengah. Usaha mikro adalah usaha produktif milik orang perorangan dan/atau badan usaha perorangan yang memiliki hasil penjualan tahunan atau omzet paling banyak sebesar Rp 300 juta, sedangkan usaha kecil memiliki omzet tahunan lebih dari Rp 300 juta, sampai dengan paling banyak Rp 2,5 milyar. Lalu, usaha menengah memiliki omzet tahunan lebih dari Rp 2,5 milyar, sampai dengan paling banyak Rp 50 milyar. Menurut data Kementerian Koperasi dan UMKM, sekitar 98,7\% usaha di Indonesia merupakan usaha mikro dan berkontribusi terhadap Produk Domestik Bruto (PDB) Indonesia hingga mencapai 36,82\%.

Dinas Koperasi Usaha Kecil Menengah dan Tenaga Kerja Kota Banjarbaru (Diskopukmnaker) adalah salah satu bagian kantor pemerintah yang mengurus pekerjaan pemberdayaan dan pelatihan UMKM yang beralamat di Jalan Soekarno Hatta - Trikora, Kelurahan Loktabat Selatan, Kecamatan Banjarbaru Selatan, Kota Banjarbaru, Provinsi Kalimantan Selatan. Diskopukmnaker menjelaskan bahwa produk UMKM lokal yang berhasil menembus pasar internasional terbilang masih sedikit. Jika dibandingkan dengan produk sejenis dari negara luar, produk UMKM Indonesia kalah saing baik dari segi kualitas dan harga.

Kunci utama untuk membuat sebuah desain kemasan yang baik adalah kemasan tersebut harus simpel (sederhana), fungsional dan menciptakan respon emosional positif yang secara tidak langsung "berkata", "Belilah saya." Kemasan harus dapat menarik perhatian secara visual, emosional dan rasional. Sebuah desain kemasan yang bagus memberikan sebuah nilai tambah terhadap produk yang dikemasnya (Iwan, 1999).

Desain kemasan dan pemanfaatan teknologi dapat menjadi solusi atas permasalahan yang terjadi. Kemasan yang baik dan unik dapat memperluas target marketing UMKM serta memenuhi standar kualitas sehingga dapat dipasarkan ke marketplace yang lebih besar dan berdampak positif dengan meningkatnya omzet.

Pengabdian kepada masyarakat ini bertujuan untuk membantu UMKM lokal khususnya untuk pemula usaha mikro dalam merancang desain kemasan yang bekerjasama dengan Dinas Koperasi Usaha Kecil Menengah dan Tenaga Kerja Kota Banjarbaru.

\section{METODE}

Metode pelaksanaan kegiatan pengabdian kepada masyarakat yang dilakukan dapat ditunjukkan oleh Gambar 1 dibawah ini. 


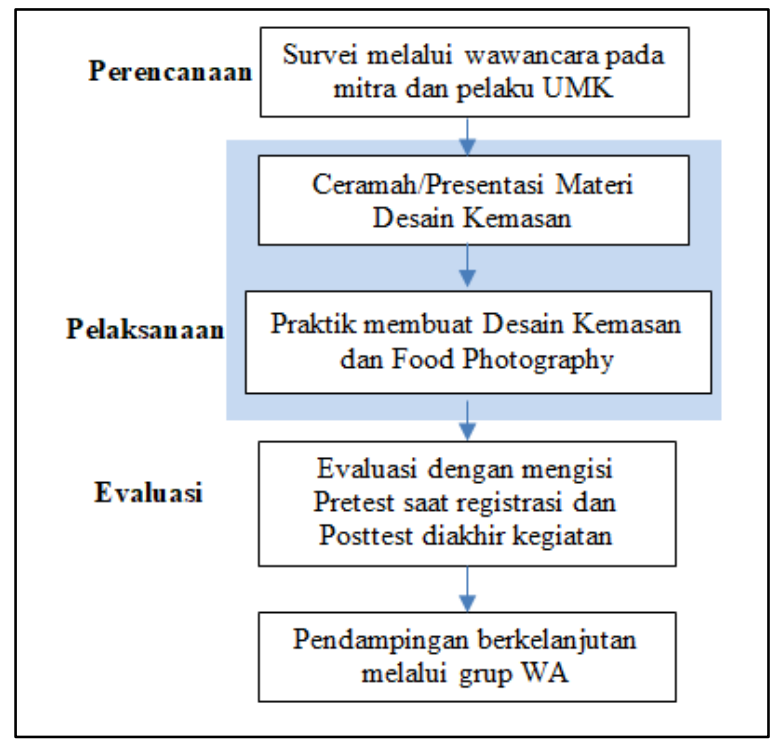

Gambar 1. Metode Kegiatan

Sebelum pelaksanaan kegiatan pengabdian langkah yang pertama yaitu survei kebutuhan mitra melalui wawancara, subjek dari penelitian ini adalah para Pelaku Usaha Mikro dan Kecil Kota Banjarbaru sebanyak 20 orang. Dinas Koperasi, UKM dan Tenaga Kerja Kota Banjarbaru merupakan mitra yang mendampingi dan memfasilitasi para pelaku Usaha Mikro dan Kecil Kota Banjarbaru. Hasil dari survei tersebut didapatkan pelaku UMK minim inovasi dalam mengembangkan produk khususnya desain kemasan sehingga sulit untuk memasarkan ke marketplace yang lebih besar serta masih banyak UMK yang gagap teknologi sehingga tidak mengetahui cara memanfaatkan aplikasi desain berbasis mobile dan pemanfaatan media sosial.

Sebelum kegiatan pelatihan dimulai tim pelaksanan melakukan pengukuran suhu badan (sesuai protokol kesehatan) dan memberikan form pretest untuk mengidentifikasi tingkat pengetahuan dan pemahaman peserta terhadap desain kemasan.

Metode pelaksanaan kegiatan pengabdian kepada masyarakat dilaksanakan melalui pelatihan dengan pemanfaatan modul yang telah disediakan yaitu dengan metode ceramah dengan teknik presentasi dilanjutkan dengan diskusi dan pelatihan membuat desain kemasan serta food fotografi. Selain itu, mereka juga diberikan contoh cara membuat desain kemasan yang menarik pembeli.

Evaluasi kegiatan ini dilakukan dengan dua cara yaitu memberikan project latihan desain kemasan sesuai produk masing-masing peserta dan Kuesioner yang dilaksanakan sebelum dan sesudah kegiatan pelatihan desain kemasan.

Setelah semua rangkaian kegiatan pengabdian, para pelaku UMK juga mendapatkan pendampingan berkelanjutan melalui grup WhastApp sebagai wujud dukungan tim.

\section{HASIL DAN PEMBAHASAN}

Dinas Koperasi, UKM dan Tenaga Kerja Kota Banjarbaru memfasilitasi kegiatan ini dengan baik, untuk menjaring peserta kegiatan dipublikasikan di laman aplikasi UMKM "Idaman Banjarbaru dalam Genggaman" disertai dengan syarat tertentu dan para peserta yang memenuhi persyaratan dapat langsung melakukan pendaftaran keikutsertaan dalam pelatihan melalui laman aplikasi, sehingga pelatihan tepat sasaran.

Kegiatan pengabdian ini merupakan peningkatan wawasan para Pelaku Usaha Mikro dan Kecil dalam menghasilkan kualitas serta inovasi baru pada label kemasan melalui Pelatihan Desain Bagi Pemula Pada Pelaku Usaha Mikro dan Kecil Kota Banjarbaru, dilaksanakan pada tanggal 2 \& 3 Maret 2021. Kegiatan ini berjalan dengan lancar, peserta pelatihan terlihat antusias dengan materi pelatihan yang diberikan. Hal ini terlihat dari awal hingga akhir acara, semua peserta dapat mengikuti dengan baik. 
Materi pengetahuan tentang desain kemasan produk, peran kemasan dalam pemasaran produk, standar kemasan yang sesuai dengan produk, komponen desain kemasan, dan praktik desain kemasan diberikan pada hari pertama pelatihan. Pada hari kedua peltihan diberikan materi food fotografi dan pelatihan fotografi produk serta pemasaran melalui media sosial.

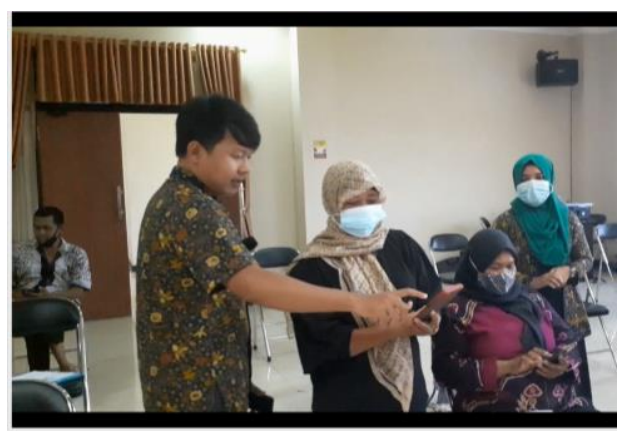

Gambar 2. Momen ketika peserta bertanya kepada pemateri

Pada saat kegiatan, kami juga lakukan pendampingan seperti Gambar 2 diatas. Yaitu pendampingan dalam memasang aplikasi canva pada smartphone peserta, seta penggunaan aplikasi tersebut ketika para peserta melakukan pembuatan desain terhadap produk mereka sendiri.

Metode pelaksanaan kegiatan pengabdian kepada masyarakat dilaksanakan melalui pelatihan dengan pemanfaatan modul yang telah disediakan yaitu dengan metode ceramah dengan teknik presentasi dilanjutkan dengan diskusi dan pelatihan membuat desain kemasan serta food fotografi. Selain itu, mereka juga diberikan contoh cara membuat desain kemasan yang menarik pembeli dengan memanfaatkan aplikasi android yang ada pada ponsel seluler. Kemudian para peserta dipersilahkan membuat desain, mengambil foto produk dan memasarkan produk melalui media sosial.

Pelaksanaan program ini melibatkan dua orang mahasiswa agar kegiatan dapat berjalan lebih lancar. Kegiatan tanya jawab dilakukan bersamaan dengan penyajian materi. Para peserta dapat langsung berdiskusi dengan para pemateri secara langsung untuk memahamkan materi dan saling berbagi pengalaman terkait dengan masalah yang tengah dibahas dalam materi bersangkutan. Pada pelaksanaan praktik desain kemasan dengan memanfaatkan aplikasi android Canva peserta didampingi oleh tim, pada pelaksanaan praktik food fotografi masingmasing peserta membawa sampel produk agar mendapatkan foto terbaik sebagai bahan promosi melalui media sosial. Kegiatan ini dilaksanakan di aula Dinas Koperasi, UKM dan Tenaga Kerja Kota Banjarbaru.

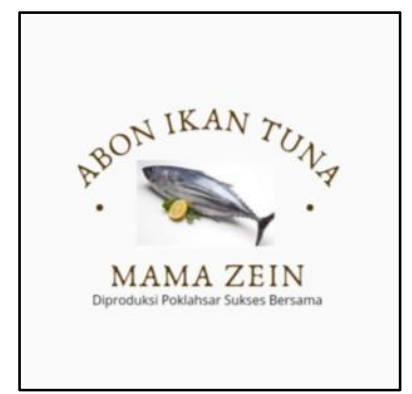

Gambar 3. Salah Satu Hasil Desain Dari Peserta

Materi yang disajikan oleh tim pengabdi dapat diterima, dicerna, dan dipahami peserta dengan baik. Para peserta sebagian besar berhasil mendesain logo produk mereka sendiri menggunakan aplikasi canva seperti yang terlihat di Gambar 3 diatas. Pelaksanaan praktik desain label kemasan dan food fotografi juga berjalan dengan lancar. Jumlah peserta yang sebanding dengan jumlah tim pelaksana yang berperan sebagai instruktur dan tutor menjadikan pelatihan ini menjadi lebih kondusif. 
Evaluasi kegiatan pengabdian kepada masyarakat ini dilakukan dengan dua cara, pertama evaluasi hasil dilihat dari praktik mandiri oleh masing-masing peserta dan penilaian kedua didapat dari kuisioner.

Sebelum kegiatan pengabdian dimulai, tim pelaksana mengidentifikasi tingkat pengetahuan peserta dengan cara memberikan pretest secara tertulis. Pertanyaan berjumlah 10 soal dengan 8 pertanyaan seputar desain label kemasan dan 1 pertanyaan mengenai food fotografi dan 1 pertanyaan mengenai media sosial. Pertanyaan-pertanyaan yang diajukan dapat dilihat pada tabel 1 dibawah ini.

Tabel 1. Pertanyaan Pretest

\begin{tabular}{cl}
\hline No. & \multicolumn{1}{c}{ Pertanyaan } \\
\hline 1 & Apakah anda pernah mendapatkan pelatihan dengan tema desain kemasan produk \\
& seperti ini sebelumnya? \\
2 & Apakah desain kemasan produk anda sudah sesuai dengan apa yang anda inginkan? \\
3 & $\begin{array}{l}\text { Apakan selama ini anda merancang desain kemasan produk dengan menggunakan } \\
\text { bantuan jasa profesional? }\end{array}$ \\
4 & Apakah anda sudah paham fungsi dari sebuah desain kemasan produk? \\
5 & Apakah anda mengetahui elemen dasar dari sebuah desain kemasan produk? \\
6 & Apakah anda sudah mengetahui jenis bahan yang cocok untuk kemasan produk anda? \\
7 & Apakah anda telah mempertimbangkan aspek terhadap lingkungan dalam mendesain \\
& kemasan produk anda? \\
8 & Apakah anda sering menggunakan aplikasi dalam mendesain kemasan produk? \\
9 & Apakah anda telah mengetahui tentang dasar-dasar dalam fotografi khususnya untuk \\
& produk anda?
\end{tabular}

Kemudian, setelah melaksakan kegiatan pengabdian, kami juga mememberikan pertanyaan-pertanyaan posttest untuk mengetahui besaran peningkatan kemampuan peserta terhadapt materi yang disampaikan. Pertanyaan-pertanyaan yang diajukan dapat dilihat pada tabel 2 dibawah ini.

Tabel 2. Pertanyaan Posttest

\begin{tabular}{cl}
\hline No. & \multicolumn{1}{c}{ Pertanyaan } \\
\hline 1 & $\begin{array}{l}\text { Apakah dengan mengikuti pelatihan ini anda sudah mendapatkan pengetahuan lebih } \\
\text { dalam tentang desain kemasan produk? }\end{array}$ \\
2 & $\begin{array}{l}\text { Apakah setelah pelatihan ini anda akan mencoba mendesain kemasan produk yang sesuai } \\
\text { dengan ilmu yang didapat tadi? }\end{array}$ \\
3 & $\begin{array}{l}\text { Apakah setelah pelatihan ini anda akan mencoba mendesain sendiri kemasan produk } \\
\text { anda? }\end{array}$ \\
4 & $\begin{array}{l}\text { Apakah setelah pelatihan ini anda sudah paham fungsi dari sebuah desain kemasan } \\
\text { produk? }\end{array}$ \\
5 & $\begin{array}{l}\text { Apakah setelah pelatihan ini anda mengetahui elemen dasar dari sebuah desain kemasan } \\
\text { produk? }\end{array}$ \\
6 & $\begin{array}{l}\text { Apakah setelah pelatihan ini anda sudah mengetahui jenis bahan yang cocok untuk } \\
\text { kemasan produk anda? }\end{array}$ \\
7 & $\begin{array}{l}\text { Apakah setelah pelatihan ini anda mampu mempertimbangkan aspek terhadap } \\
\text { lingkungan dalam mendesain kemasan produk anda? }\end{array}$ \\
8 & $\begin{array}{l}\text { Apakan anda sudah bisa mendesain kemasan produk menggunakan aplikasi yang } \\
\text { diajarkan pada pelatihan ini? }\end{array}$ \\
9 & $\begin{array}{l}\text { Apakah setelah pelatihan ini anda lebih memahami tentang dasar-dasar dalam fotografi } \\
\text { khususnya untuk produk anda? }\end{array}$ \\
10 & $\begin{array}{l}\text { Apakah setelah pelatihan ini anda akan memaksimalkan penggunaan media sosial dalam } \\
\text { pemasaran produk? }\end{array}$ \\
\hline
\end{tabular}




\begin{tabular}{cccc}
\multicolumn{4}{c}{ Tabel 3. Hasil Evaluasi } \\
\hline No. Soal & Pretest & Posttest & Peningkatan \\
\hline 1 & 1,950 & 3,750 & 1,800 \\
2 & 2,400 & 3,650 & 1,250 \\
3 & 1,200 & 3,300 & 2,100 \\
4 & 2,500 & 3,750 & 1,250 \\
5 & 1,450 & 3,350 & 1,900 \\
6 & 1,400 & 3,500 & 2,100 \\
7 & 1,250 & 3,450 & 2,200 \\
8 & 1,050 & 3,400 & 2,350 \\
9 & 1,650 & 3,600 & 1,950 \\
10 & 2,900 & 3,800 & 0,900 \\
\hline
\end{tabular}

Hasil dari pretest yang ditunjukkan pada tabel 3 diatas. Rerata nilai pretest adalah 1,775, jika dibuat dalam persentase maka hasilnya adalah 44,75\%. Adapun hasil dari kuisioner setelah pembelajaran dilaksanakan, rerata nilai posttest adalah 3,555, Jika diubah menjadi persentase, maka hasilnya adalah $88,87 \%$.

Berdasarkan hasil penilaian posttest dan menghitung peningkatan kemampuan dalam membuat desain kemasan dan food fotografi, secara umum para peserta telah mengetahui dasar-dasar merancang desain kemasan, mampu mendesain kemasan produk, mampu memanfaatkan aplikasi mobile untuk mendesain kemasan produk dan telah mampu memfoto produk sendiri tanpa bantuan jasa profesional serta memanfaatkan media sosial untuk memasarkan produk. Penilaian tersebut merupakan salah satu bahan evaluasi untuk bagi tim pelaksana supaya memberikan layanan pelatihan yang lebih baik lagi

Setelah pelaksanaan kegiatan pengabdian ini selesai dilaksanakan, para pelaku UMK akan tetap didampingi dalam membuat desain kemasan label dengan memanfaatkan media sosial melalui WA grup, sebagai wujud dukungan tim pelaksana terhadap produk UMKM lokal agar dapat menembus pasar nasional.

\section{KESIMPULAN}

Berdasar hasil pelaksanaan kegiatan pengabdian kepada masyarakat ini dan uraian pembahasan di atas, dapat disimpulkan, pelatihan ini memberikan beberapa materi pengetahuan tentang desain kemasan produk, peran kemasan dalam pemasaran produk, standar kemasan yang sesuai dengan produk, komponen desain kemasan, pelatihan desain kemasan dan food fotografi serta pemasaran melalui media sosial untuk menghasilkan kualitas serta inovasi baru pada label kemasan. Materi yang disajikan dapat diterima, dicerna, dan dipahami peserta dengan baik. Jumlah peserta yang sebanding dengan jumlah pengabdi menjadikan pelatihan ini menjadi lebih kondusif. Kegiatan berlangsung lancar, tepat waktu dan sesuai dengan yang diharapkan dan para pelaku umk dapat berkomunikasi dengan para pembicara dan peserta lain dengan baik.

\section{DAFTAR PUSTAKA}

Creswell, J. W. (2009). Research Design: Pendekatan Kualitatif, Kuantitatif, dan Mixed. Yogyakarta: Pustaka Pelajar.

Kartajaya, Hermawan. (1996). Marketing Plus 2000 Siasat Memenangkan Persaingan Global. PT. Gramedia Pustaka Utama, Jakarta.

Klimchuk, M. R. \& Krasovec, S. A. (2007). Desain Kemasan. Penerbit Erlangga, Jakarta.

Mulyana, D. (2000). Ilmu Komunikasi Suatu Pengantar. Bandung: PT. Remaja Rosdakarya.

Niode, I. Y. (2009). Sektor Umkm Di Indonesia: Profil, Masalah, Dan Strategi Pemberdayaan. Jurnal Kajian Ekonomi Dan Bisnis OIKOS-NOMOS, 2(1). Retrieved from 
http://repository.ung.ac.id/get/kms/9446/ Jurnal-Sektor-UM-Di-Indonesia-ProfilMasalahDan-Strategi-Pemberdayaan.pdf

Rachmawati, F. (2018). Penerapan Digital Marketing Sebagai Strategi Komunikasi Pemasaran Terpadu Produk Usaha Kecil Dan Menengah (UKM) Pahlawan Ekonomi Surabaya. Universitas Islam Negeri Sunan Ampel Surabaya

Sudaryanto, Ragimun, \& Wijayanti, R. R. (2013). Strategi Pemberdayaan UMKM Menghadapi Pasar Bebas Asean. Retrieved from https://www.kemenkeu.go.id/sites/default/files/strategi pemberdayaan umkm.pdf

Stanton, William J. \& Y. Lamarto. (1988). Prinsip Pemasaran. Penerbit Erlangga, Jakarta.

Sugiyono. (2015). Metode Penelitian \& Pengembangan Research and Development. Bandung: Alfabeta.

Wirya, Iwan. (1999). Kemasan yang Menjual. PT. Gramedia Pustaka Utama, Jakarta. 


\section{Halaman Ini Dikosongkan}

